In the discussion of tissue culture, Prof. Huzella described experiments on the effect of magnetic fields on heart cultures. His pupil, Dr. Julia Lengyel, showed that constant magnetic fields affect the intracellular substance, but have no effect on the cells themselves. Prof. Huzella dealt with the effect of intermittent magnetic fields. The cells are found to grow along the lines of force. Prof. Huzella attributes the effect to induced electric currents in the medium. In the discussion, the alternative explanation was suggested that the living cell is the seat of circulating electric currents, and so has a magnetic moment. These results link up with previous findings by Prof. Huzella and others that cells always tend to grow along lines of strain, whether caused by stretching, crystallisation in the culture medium, or in other ways.

Prof. J. de Haan and K. J. Feringa, of Groningen, have devised a method by which comparatively thick explants can be grown while being perfused with a physiological fluid. They were able to demonstrate the differentiation of wandering cells from a rabbit exudation into typical lymph tissue, and even the formation of non-nucleated cells resembling red blood corpuscles. Their experiments were illustrated by a cinematograph film.

Prof. C. C. Speidel, of Virginia, has also found the cinematograph of great value in studying the growth, irritation, and repair of nerves. He works on anæsthetised tadpoles, which are fixed under the microscope. The tip of the tail is cut off, and in the rapid process of regeneration the details of nerve outgrowth can be followed in vivo. By his remarkably clear and detailed observations, Prof. Speidel has been able to settle many doubtful points in neural physiology.

Dr. H. Okkels, of Copenhagen, described work on the dynamic cytology of the thyroid gland. When called into sudden activity, the cells undergo a cycle of changes. There is a phase of synthesis of the secretion, in which the mitochondria play the decisive part, and then a phase of discharge, which is governed by the so-called Golgi apparatus. Dr. E. S. Duthie, of Dublin, has found similar phenomena in the cells of various digestive glands.

In the discussion on virus growth, there was universal testimony to the value of tissue cultures as a means of virus propagation. Dr. G.H. Eagles, of London, indeed, maintained that viruses can be grown in cell-free media, and his paper provoked a long and interesting discussion. He agrees, however, that the presence of living cells is favourable to virus growth. Tissue cultures not only form a convenient substitute for animal propagation in the culture of viruses, but also, as was shown in a series of papers from different workers, allow of observations on cell pathology and immunity phenomena that would be impossible on the living animal.

In the field of Entwicklungsmechanik, there were a series of important communications. Dr. H. B. Fell, of Cambridge, has obtained differentiation of kneejoints in explants of chick limb-buds taken from the egg at a stage when no differentiation is visible. Dr. R. G. Canti showed a fascinating film of the process of differentiation in Miss Fell's preparations. Prof. R. Chambers, of Now York, has found that explants of mesonephric tubule segments are converted into closed tubules. When this stage is reached, phenol red accumulates in the lumina of the segments. This effect depends on the maintenance of the cell respiration, and is an instance of cells taking on their physiological functions in vitro.

J. Holtfreter, of Berlin, described work on the amphibian embryo, which he has succeeded in cultivating in vitro. C. $\mathrm{H}$. Waddington, of Cambridge, who has devised a method for keeping the warmblooded chick embryo alive out of the egg for a few days, also described the result of experimental interference with normal development. Both workers have been able to show the determining effect of the endoderm for differentiation in a number of beautiful experiments. Holtfreter, describing his work on the 'organiser', showed that it is present in all adult tissues, and in a latent form in the egg and in embryo tissues. In the latter, no organising power is shown until the tissue is boiled. Needham, Waddington and Needham have made it practically certain that the organiser is a chemical substance by obtaining neural tube formation in the embryo with petrol-ether extracts (see Nature of August 12, p. 239).

This demonstration of what may be called an intra-embryonic hormone is of great interest. Nevertheless, its ubiquitous occurrence tends to throw the emphasis on the innate properties and responses of the embryonic tissue, rather than on the chemical stimulus from without, as a determining factor in differentiation.

The present Congress differed from previous ones, in that the scope was widened to include cell respiration and metabolism and cell electrophysiology, to each of which a whole day was devoted. Prof. E. D. Adrian, of Cambridge, opened the discussion on electrophysiology, and papers were read on biological potentials and currents, and the mechanism of selective passage and concentration of ions by cell membranes. Dr. M. Dixon, of Cambridge, opened the discussion on cell respiration. Prof. A. SzentGyörgyi, of Szeged, read a provocative paper on non-enzymic catalysts of cellular oxidation. One useful feature of the day's discussion was the demonstration of the wide variety of oxidation mechanisms, and the differences in response to cyanides and other respiratory inhibitors, that occur in the different phyla of the plant and animal kingdom. This must have been especially valuable to the biochemists, who have perhaps confined their attention to too few kinds of organisms.

B. Woolf.

\title{
Research in the British Non-Ferrous Metal Industries
}

$\mathrm{T}$ $\mathrm{HE}$ annual meeting of the British Non-Ferrous Metals Research Association was held at Birmingham on June 19, and the report for the past year shows that, in spite of the difficulty of the times, the expenditure on research has been slightly increased to $£ 17,000$ a year.

Brighter homes should resuit from the choice of suitable metals and alloys arising from the study which is being made of the resistance to tarnishing of polished surfaces of metals used for finger plates, door knobs, shop fronts and the like. Much work has also been done on an investigation dealing with the factors involved in the bursting of water pipes due to frost, concerning which little is at present known. The mechanism of ice formation and the behaviour of freezing water in pipes of different 
materials are being studied in detail. New lead alloys, containing small quantities of cadmium and tin or antimony, developed by the Association for cable sheathing, are now finding increasing application in other fields. Tests are also being conducted with new materials for water pipes in which lead is alloyed with 0.05 to 0.06 per cent of tellurium. The effect of various soils on pipes of copper and these new alloys is also being investigated with the view of discovering the most suitable material for use in particularly corrosive soils.

A large amount of work of value in other directions is also recorded in the report. Methods have been devised by which small quantities of impurities in tin and lead can be determined spectroscopically in a few minutes and with considerable exactness. Further work has also been done on copper and nickel and a start has been made with aluminium.

New materials for service at high temperatures are being developed by the addition of small quantities of various elements to copper-nickel alloys. The effects of the addition of aluminium and silicon to cupro-nickel containing 20 per cent or more nickel are being studied, and alloys have been found which give promise of useful commercial application. both with regard to maintenance of strength and resistance to steam corrosion at elevated temperatures.

An extensive service trial is being carried out by the London Midland and Scottish Railway Co. of new materials developed by the Association for firebox construction. In a locomotive the copper firebox is held in position by a number of rivetted copper stay rods, and it is estimated that, on the average, half the time a locomotive spends in the repair shops is due to failures in these stays. The trouble has now been traced to corrosion caused by boiler water leaking through the rivetted heads. By alloying the copper with small quantities of other substances and utilising a special heat treatment, the cause of the trouble is likely to be removed.

The utilisation of certain types of Empire copper for special purposes will be facilitated should investigations in progress on the removal of small quantities of bismuth from copper be successful.

The report records the practical completion of the researches which led to the production by the Association of aluminium brass condenser tubes. Their adoption practically solved the problem of the corrosion of condenser tubes in cases in which cupronickel tubes would be too costly. Other investigations in progress include those on the casting of aluminium and brass. The latter research has led to considerable improvements in the production of rolled brass sheet, of which tens of thousands of tons a year are produced in Great Britain.

\section{A Continuous Gas Indicator}

$\mathrm{T}$ HE technique of accurate gas analysis by chemical analysis is difficult, and expertness in the art can be acquired only by long apprenticeship. Moreover, the chemical method of analysis is not directly and readily adaptable to indicating and recording with accuracy the extent to which a constituent gas is present in a gaseous mixture. Such information is of very great importance in many industrial operations, and although chemical indicators and recorders, more especially for indicating and recording the presence of carbon dioxide and carbon monoxide, are available, their performance is, in general, not very satisfactory.

It is not surprising therefore that, in the last twenty years or so, physical principles have been employed in the design and construction of such instruments. These have included instruments de. pendent for their indications on density, calorific intensity, thermal conductivity, and in the case of an indicator recently devised by I. Fagelston, a combination of viscosity and velocity of effusion.

The principle of this last instrument is simple. The gaseous mixture and a standard gas flow through two similar capillary tubes, the outlet ends of which are enlarged and closed by two platinum plates pierced with similar orifices. The gases are sucked through the respective capillary tubes and orifices by a pump, and any difference of pressure at the exit ends of the capillary tubes, arising from difference in composition of the gases flowing in the tubes, is indicated by the difference of level of liquid in the limbs of a U-tube manometer connected with the respective ends.

Two forms of instrument incorporating this principle have been put on the market by Messrs. Griffin and Tatlock, Ltd. The first form, known as the "Air Type", uses air as the standard comparison gas; in the second form, known as the "Petrol Type", the comparison gas is made from the gas being analysed, by removing the constituent being determined. Generally an accuracy of indication of the order 0.05 per cent is possible with the instruments; very small vapour concentrations can be indicated to within 0.005 per cent. The instruments have numerous technical and scientific applications, including, for example, the indication of organic solvents, petrol vapour in air, the evaluation of adsorbents, in coal carbonisation for indicating carbon dioxide and hydrogen sulphide, and for the analysis of industrial gases, including the rare gases, for determining safety in connexion with chemical and engineering plant, and for indicating the humidity of gases.

\section{University and Educational Intelligence}

RESEARCH work in Slavonic countries is listed in catalogues which are being compiled and issued by the Russian Department of the University of Birmingham. Pamphlets relating to work $(a)$ in progress and (b) already published in Czechoslovakia and Poland in 1931-32 have already been issued and these will be followed by catalogues of work in three other Slavonic countries. The lists are arranged according to universities and faculties.

SUPERvised correspondence study of a new type has been introduced in the State of Nebraska with the object of widening at a minimum of expense the range of the curricula of the smaller high schools. The system is described in an article contributed by Prof. Platt of the University of Nebraska to the June number of School Life. The school time-table provides periods for the work and the scripts are regularly dispatched to the correspondence centre for examination and criticism. The supervising teacher does not need to be a specialist in all the subjects of the correspondence courses. It is his business to see that the pupils have the proper materials, attitude and environment, to interpret the questions, guide the pupils in the use of encyclo- 